\title{
How Business Process Managements Impacts Decision Making Process of Fashion Start Up Business
}

\author{
Nia Alprilia, Manahan Siallagan \\ School of Business and Management \\ Institut Teknologi Bandung, \\ Bandung, Indonesia \\ nia.alprilia@sbm-itb.ac.id
}

\begin{abstract}
- this research aims to identify decision making process of startup business and understanding its relationship with core of their business process management. Business process management provide in the startup business usually is the core of system that start up business to run their business systematically with what start up wants. The business process management is a vital asset and analyzing the correlation of the business process management with the impacts of decision making process. Existing literature, both theoretical and empirical, is understanding to identify the state of knowledge associated with this question to fashion start up in Bandung City. The empirical research was co-ordinate via a survey using interview of fashions start up in Bandung City. The results of the survey provide source of data in relation to a variety of practices associated with business process and decision making process in startup business especially in Bandung city. This research gives new empirical evidence about the value of business process that impact the decision making process from fashion start up in Bandung City context. This research give the knowledge how to decide the decision making based on business process. Business process management will impact the continuous improvement in start up business. How to solve the problem in the core of business is needed this research to solve it.
\end{abstract}

Keywords - Decision Making, business process, fashion start up, Bandung

\section{INTRODUCTION}

\section{A. Background}

Every business definitely has the business process. Interviewing 10 startup business that has been running their business in 1 year in Bandung City, the result indicates that all of them has business process in generally but they all don't implemented that in a document. Every one that involved in their start up not specific know about the business process which running in their start up. All of them do not know specifically about business process and the important thing to use it.

Idealism of business and create the start up are considered because every business wants to growth and develop. The start up business could not know the fundamental of the frame work of their business process. They will be difficult to decide a decision making to growth competitiveness of their business, to moving forward and to achieve full potential. By business process, they can decide what the first step they should do improve, the first division that could face the opportunity and how they will solve problem in every division of business process so that they could be togetherness moving forward again. 10 starts up business interviewing and analyzing in one year there is no one who could significantly growth in their business and there are some start up whom decreasing their profitability and performance.

Most of 10 starts up that interviewed, they are in running their job description by themselves and not integrated each other in the division that they made in their start up. The brake down of their main process of business or frame work not define well and for each other in their team there is no same frame work and targeted timeline to run the business it could make conflict, problem, and miss-communication each others. Some of the business, I analyze often to change the internal team or crush the team.

Business process management is not simple as start up understanding about it. Business process management is Business process management is core fundamentals capital about management discipline. Organizational achievement can realize with continuous improvement of business process [1]. Business process management have important act to running the business so that it will depends on core division, activities, actor, and the value chain that will effect to the customer [2]. Business process management could measure the key performance indicator in every activity of startup business [3]. 10 of starts up that have been interviewed indicate that they do not understand well of the business process and the benefit of it and they do not document the business process that they are doing now.

The decision making is making consideration to take action from several alternatives that possible or not [4]. The decision making is complex of consideration how the entrepreneur could make good decision for developing the start up. The decision making has some processes start from information processing, making alternative generation, decision closure and alternative evaluation [5].

\section{B. Purpose and Research Question}

By this paper, I propose this research as to understand how the business process impacts the decision making process of fashion start up business in Bandung City. The ultimate goal of 
this research is to understand the business process management that running by start up in Bandung and the decision making, is there any correlation in both of them. All research uses qualitative data and interviewing the startup fashion in Bandung that has some criteria. The criteria of startup that interviewing are the employee is less than 15 peoples, has revenue at least 1 million per month, domicile in Bandung and has been running the startup minimum 1 year. By knowing the business process management that impact in decision making will help other start up to understand their business process well and could help them to decide the best decision making for their business.

\section{LITERATURE REVIEW}

\section{A. The Background of Business Process Management and Decision Making Process}

Business process management is a management discipline that could manage the objective of organization that could be achieved through organization's business processes and optimizing to deliver value to customer [6]. Business process management consists of goals oriented, internal condition and external conditions to analyze, realize, to do continuous improvement process to sustainable process governance [7].

Decision making process is complex human behavior and how they could solve the problem. The process of decision making strongly linked with problem solving [8]. Decision making process is decided the possible action from compute the alternative of criteria to solve the problem. Problem solving is crucial activities that should accomplish with right determination alternatives.

\section{B. Business process management principal}

Business process management is the fundamental capital of management discipline [9]. Business process is sequence of activities starting from input, to process, and into output to deliver value for customers [10]. Core concepts of business process management based on APBMP book are following bellow

1) Business Process Management is one of a Management Discipline.

2) Core Internal Capability is an indicator of successful implemented.

3) Business Process Management have result to deliver of value to customer.

4) Business Process Management addresses end-to-end process of activities across business function.

5) Business Process Management concern about What, Where, When, Why and How activities is done and Who is conscientious for performing it.

6) Fit For Purpose and Fit For Use are requirement to be met in business process.

7) Business process should be maintain in close internally process and bring through sustainability

8) The investment is needed to make good business process for larger the capability development.
9) Internal capabilities needed to espouse company scale Business Process Management are developed along a Process Maturity Curve

10) A Business Process Management implementation involve the introduction of new activities and mission into the organization

11) Business Process Management is not a specified about framework, set of tools and methodology

12) Business Process Management implementation has supporting role that is Technology

13) Business process management implementation has goal that is a strategic decision and need executive sponsorship to realized it.

\section{Decision making principal}

In decision making process, there are six steps that should take either implicitly or explicitly based on Max H. Bazermann \& Don A. Moore.

1) Define the problem

Understanding the problem should be clearly and defining well. Identification problem do with specified the goal to make problem solving not only accomplish the symptoms that emerging.

2) Identify the criteria

Relevant criteria in decision making process resolve with more than one objective. Accomplish with more than one objective will effect in consideration process in decision making.

3) Weight the criteria

Every criterion has different relative value. Identification the criteria with positioned the relative value on it.

4) Generate the alternative

Decision making process involving identification of possible action to do after made decision.

5) Rate each alternative on each criterion

Selecting the alternative solution is in this stage and this is the difficult stage to do. Assessing the potential consequences on each of the identified criteria of selecting each of the alternative solutions should be carefully and needs a lot of consideration.

6) Compute the optional decision

Computing the optimal decision base on three ways start from multiplying the weight rating, adding the weighted ratings and choosing the solution.

\section{RESEARCH METHODOLOGY}

\section{A. Research Design and Strategy}

The research question in the paper is "how the business process management impact decision making process of fashions start up business in Bandung City". The research question categorized is in explanatory research. The methodology follows in-depth interview of some fashion start up in Bandung city. The interview type is used semi-structured interview. The qualitative data using direct interviewing with 
the fashion start up in Bandung City. Non-standardized (semistructured and in-depth) interviews are used to gather data, which are normally analyzed qualitatively.

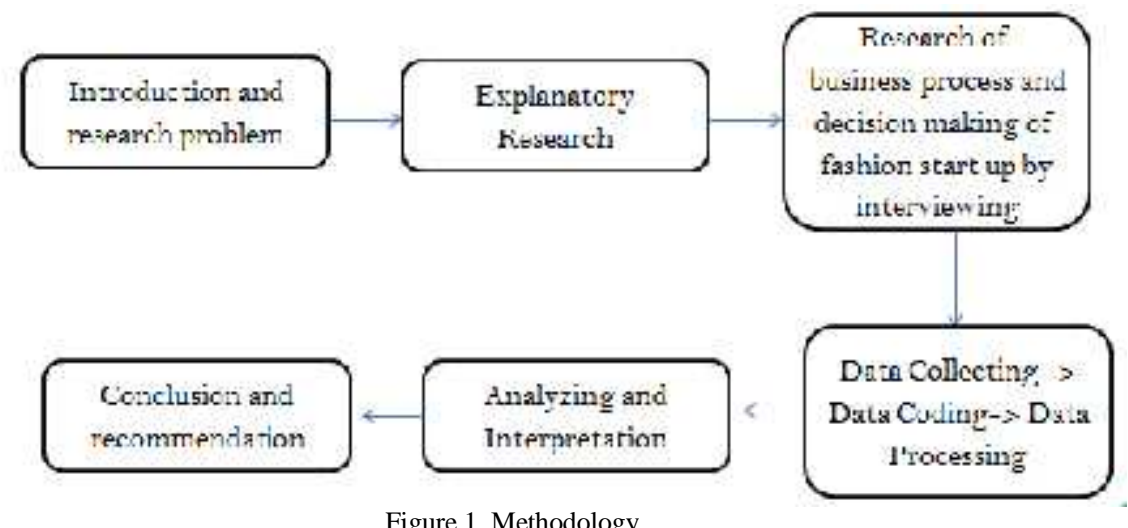

Figure 1. Methodology

\section{B. Data Collection}

The sample has chosen of 3 fashion industry which has good growth of their business for depth interview in phase 2 . We choose this type of research method because we want serve the real data and could get the idea to develop this research to more valid. This method we apply in two times of interview and face to face interview. First interview (phase 1) is to know the basically how much start up having the business process documented and second interview (phase 2) is interviewed fashion start up business that has the correlation of business and the decision making process that they do. Phase 1 and phase 2 is different object of respondents and different mean of interview propose.

TABLE I. NUMBER OF INTERVIEWS

\begin{tabular}{|c|c|c|}
\hline Criteria & Phase 1 & Phase 2 \\
\hline $\begin{array}{l}\text { Interviewing fashion } \\
\text { start up randomly to } \\
\text { know how many start up } \\
\text { has business process to } \\
\text { run their business }\end{array}$ & 10 fashion start up & \\
\hline $\begin{array}{l}\text { Interviewing more } \\
\text { detailed of fashion start } \\
\text { up to understand their } \\
\text { business process and how } \\
\text { they decide the decision } \\
\text { making to solve the } \\
\text { problem through business } \\
\text { process }\end{array}$ & & 3 Fashion start up \\
\hline $\begin{array}{l}\text { Total number } \\
\text { interview }\end{array}$ & 10 fashion start up & 3 fashion start up \\
\hline
\end{tabular}

The first stage why we representation this research because it represent of experience of our reality for run the business. The decision making is not easy to decide and we research for business which has good growth in three years. The first stage proposed to understand the business process and how the business process running in start up company.

\section{RESULTS AND DISCUSSION}

\section{A. Create and validate the problem}

\section{1) Fashion Starts Up Business Process}

Interviewing the fashion start up in Bandung with deeply on business process, the fashion starts up business process is not to complex. We interviewed the key person who has bargaining to make the decision making. Their business process is simple. The business process focuses on 5 activities that are designing, producing, marketing, sales and financing. The breakdown of the 5 activities is into some activities that improve the key activities. First activities is designing activity, the breakdown process is mood boarding from some source both online or offline, brainstorming idea, designing idea, making sample of idea design, evaluate the sample, revision the sample and fix sample. Second activity is producing activity; the breakdown process is making product, controlling and quality control. Third process is marketing activity, the breakdown process is photo product, finding channel distribution, launching and promoting. The fourth activity is sales activity, the breakdown process is selling activity to customer and B2B channel such us consignment store. The fifth activity is financing, the breakdown activity is forecasting, cash flow reporting and initial statement.

The all of board of director should understand about the framework of their business process. The business process gives them landing to make action to improve their business. The business process constrains of timeline that they do into action that they should do quickly. The business process running in 3 seasons every year. Seasons means the abilities of fashion start up to launch their new product/article. Every one season they need 4 months for complete it. The finding data of business process of fashion starts up could see in figure 1. 


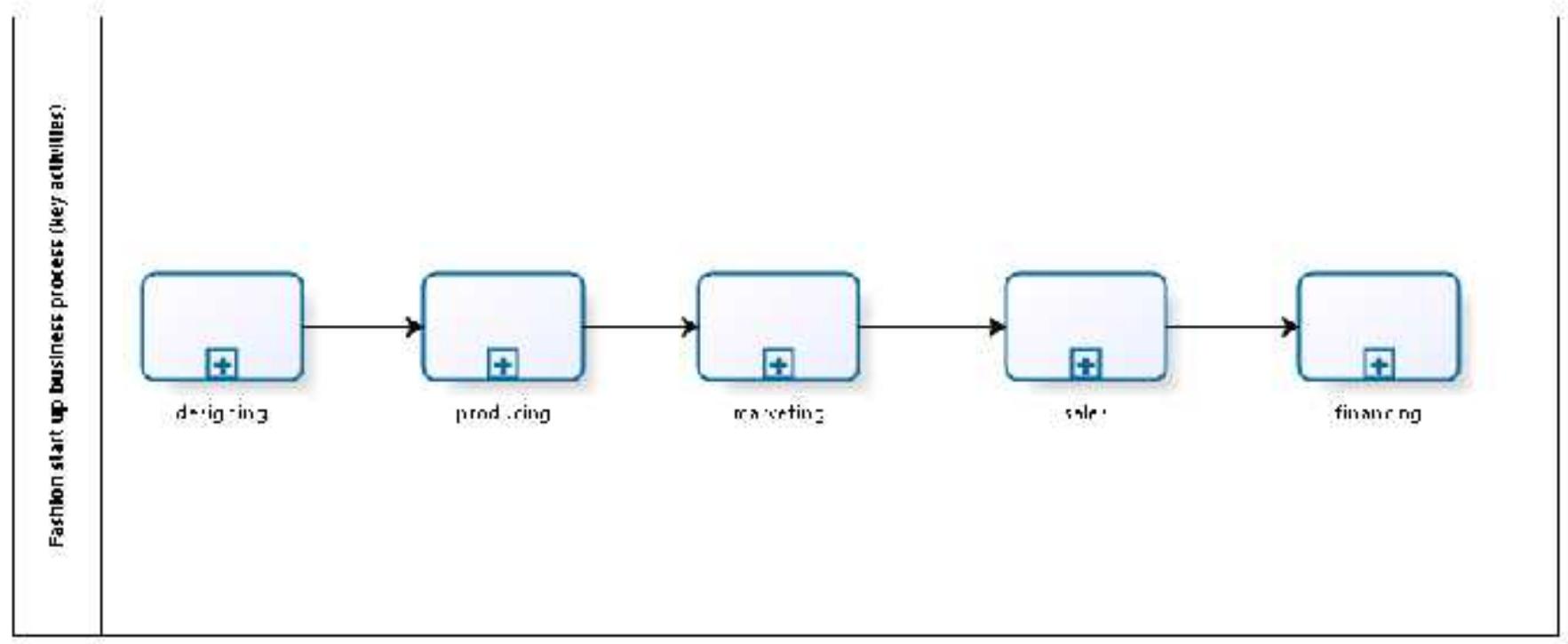

Figure 2. Business Process in fashion Start Up

The fashions start up business process focus in designing product. The process of designing consists on mood board designing, referencing, making sampling and photo product. The production process not to complex because fashion start up handed over the production process to the vendor. The process of production only for preparation the production and quality control of product. The complex activities are in marketing and sales. There are constraints of fashions start up to growth and get the high revenue every month. Marketing and sales is the first trigger to make brand awareness from peoples that will influence the sales. The financing process is aspect that supports the other activities with give information of finance circumstances.

The business process is very influence to run the business. They said that the business process is so important, because of the breakdown of the job, timeline, planning and decision making is from the business process. Business process is the fundamentals of business could run and the systematical process in the business.

The start up face problem is about the timeline constraint. The timeline of every season consist in four month-six months. The timeline is the consideration of start up to decide the decision because of timeline constraint of time. If the executions do late so the timeline also will be run late. The business process is about end-to-end process to deliver value for customer. The problem is ensuring that the value that decides by start up is delivering to customer and reaches the target. If the target does not reach it will be a problem.

\section{2) Decision Making Process}

The process of decision making could be naturally or spontaneously stated by human [11]. Every human is unique to decide the action that will do. Rational decision making process define in six step that is define the problem identify the criteria, weight the criteria, generate the alternative, rate each alternative on each criterion and compute the optional decision [12]. Defining the problem could be defining for proposed solution, missing the problem, and diagnosing the problem from symptoms that indicate it [13]. Identify the criteria and weight it to know what the relative opportunity to more benefit for decides and action that will do [14]. The next step is generated the alternative solution indecision making process and rate which the alternative that has more value of solution [15]. Than compute which one will be optimal decisions [16].

The decision making constraint of problem solving that should do to accomplish problem and take action to solve it. The importance of decision making is how could generate problem with generate the alternative solution. The decision making is also related with the goal that organizational define and ensure to deliver value to customer in every action that decide. Business process is end to end process to deliver value to customer. Delivering of value should be match between business process and the decision making for successful implementation. The decision making process in stage of identify the criteria consider of business process and it will impact the process of decision making or not. Because in identify criteria the requirement is the objectives. The one of the objective that should be considering being able to move to the next step is business process.

\section{3) How Business Process Impact Decision Making} Process

The business process is first trigger to make decision making for action. Without business process the data will not able and the process of decision making will difficult to do or it impossible to do in to take rational decision making. Although Fashion start up business has simple business process but the timeline of their business process is long and need 4 month to run in every season. The business process influenced all activities of business and the breakdown of timeline that serve in business process is to be consideration for take decision in several key activities. The key activities that could be directly 
impact the decision making process is operation which is production. The real example is the start up business use vendor for run the business because it low cost and low risk. Using vendor system effect the time of production because several vendors not commit to finished on time. The marketing and sales could run after the process of production is done. The critical time could effect is in production and directly could effect the decision making process of launching the product. The timeline of fashion start up business is described like in figure 2 .
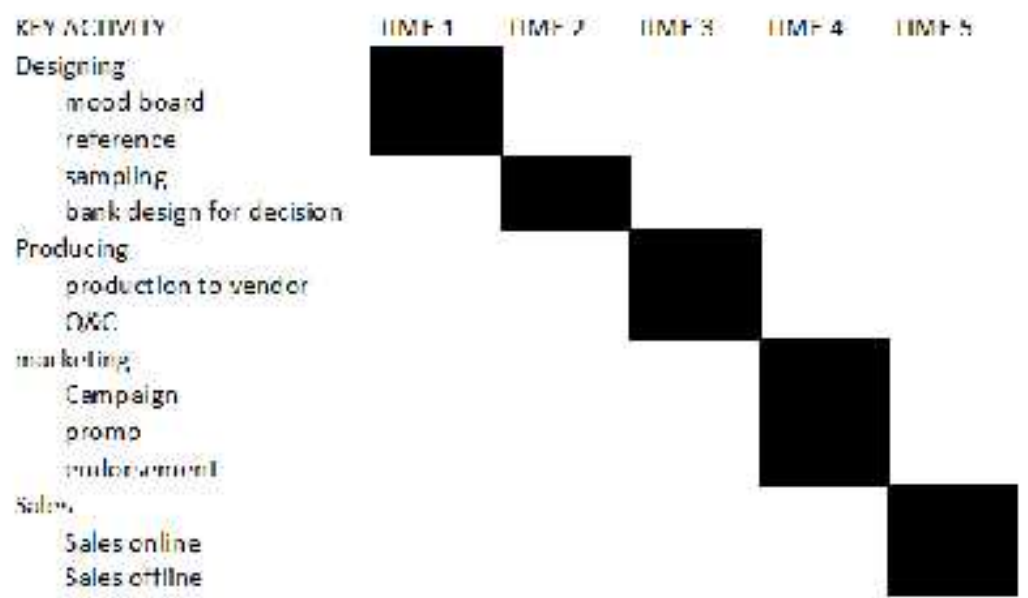

Figure 3. Timeline of Fashion Start Up

The fashions start up making decision with several steps. The first step is generated problem based on data that they have. Data analysis that bring of key activities in business process they analyze and generate problem from it. Data indicate the key performance of the action that has done in previous action. Data that serve will be the first consideration to take decision. Data is concrete action that what the business do in several time. The data said of performance of key activities in business process, indicator of achievement, indication of problem and main consideration to take decision making. The data is about the all data activity in business process. The data record of marketing performance, financial and production condition is the first consideration to decide the decision making when there is problem or planning that company do to run their target and achieve the goals.

The second consideration to make decision making is reference. Reference taking from online and offline. Online mean from internet that will give more data to support the main data that starts up have/ Offline reference mean that starts up will get the reference from their experience before to solve the problem. Business process is the first looking for decide the decision making before they find reference to solve it. They should know the process timeline will not distract if they take action to realize decision making using this second consideration to make decision.

The third consideration to take the decision is from the theory. Theory means that start up take decision making from book that have learned from book reference and match it with the starts up condition. Theory in the book could apply if the start up lack of data analyzes and reference. If the three stages do not give best decision making, the start up will take their intuition and feeling. It depends on the problem and the condition that happen in start up. The process could define in figure 3 .

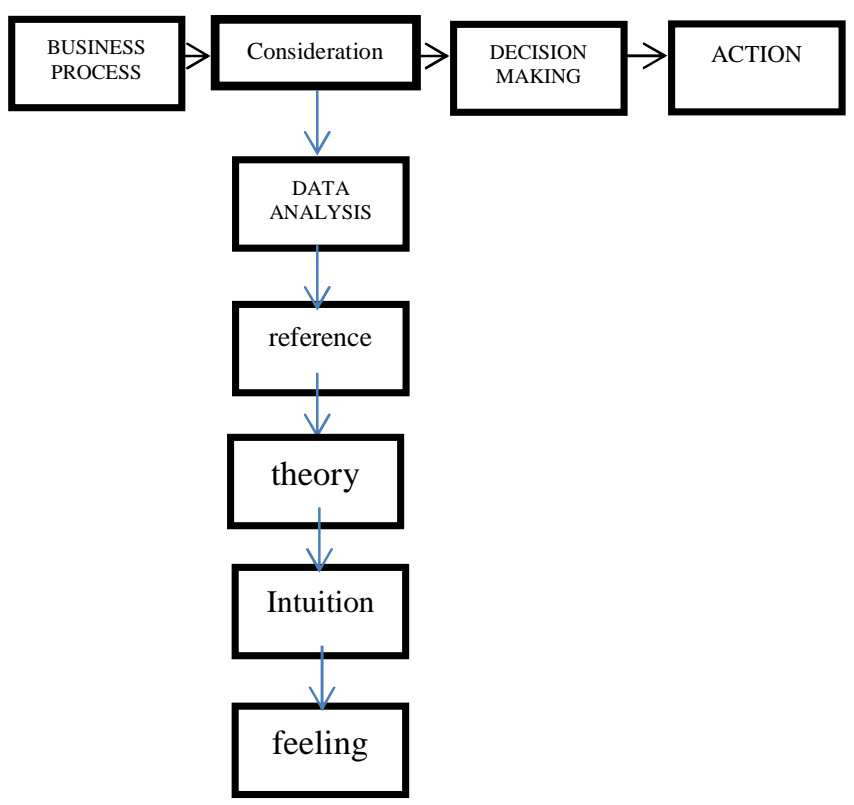

Figure 4. The framework of how business process impact decision making process result 
Information processing: from data

Alternative generation: from data analyzes

Alternative evaluation: Combine, if data not fulfill the decision process so take the other consideration.

Decision closure: Best choice from Board of directed with consideration of the data analyzes.

\section{CONCLUSION AND RECOMMENDATION}

This paper aims to understand the correlation of business process management impact the decision making process in fashion start up in Bandung. In the process, the researcher found the correlation of business process and decision making process and what impact of the business process.

Business process is useful to run the business and to increase business ability. Understand the business process to run the business will get impact of the better company visibility.

Without business process the business would not doing well because the decision making process to analyze the problem only based on what start up feel but not based on data analyzes. The decision that take by startup based on 6 step start from data analyzes, reference, theory, feeling and intuition. Business process the first trigger for run the business and the key activities to do the business. Business process gives impact to determine the key performance indicator of company. Reaching good performance need decision making process to take action.

The result of this paper also proves the use of the Business process to be useful for the company. It also has other recommendations for fashion start up in Indonesia. The recommendations are listed below:

- Documented the business process of fashion start up and the development of business process in every developing business.

- Determine the timeline of business process that will run and detailed the process in the timeline.

- Improve to consideration the decision making process based on data analyze (marketing, finance and production), reference, theory and the last is consideration based on intuition and feeling.

\section{REFERENCES}

[1] Furlan, jose, Saxena, Raju.,\&Morris,Dan.2013.BPM CBOX.Washington. ABPMP International, p53-58

[2] Furlan, jose, Saxena, Raju.,\&Morris,Dan.2013.BPM CBOX.Washington. ABPMP International, $\mathrm{p} 43$

[3] Furlan, jose, Saxena, Raju.,\&Morris,Dan.2013.BPM CBOX.Washington. ABPMP International, $\mathrm{p}$
[4] Malakooti, Behnam.2010 Decision making process: typology, intelligence, and optimization. Western Reserve University. USA. Springer Science+Business Media, LLC 2010, 23:733-746, p733

[5] Malakooti, Behnam.2010 Decision making process: typology, intelligence, and optimization. Western Reserve University. USA. Springer Science+Business Media, LLC 2010, 23:733-746, p734

[6] Furlan, jose, Saxena, Raju.,\&Morris,Dan.2013.BPM CBOX.Washington. ABPMP International, p40

[7] Furlan, jose, Saxena, Raju.,\&Morris,Dan.2013.BPM CBOX.Washington. ABPMP International, p43

[8] Malakooti, Behnam.2009. Systematic decision process for intelligent decision making. Western Reserve University. USA

[9] Furlan, jose, Saxena, Raju.,\&Morris,Dan.2013.BPM CBOX.Washington. ABPMP International, $\mathrm{p} 43$

[10] Furlan, jose, Saxena, Raju.,\&Morris,Dan.2013.BPM CBOX.Washington. ABPMP International, p43

[11] Malakooti, Behnam.2009. Decision Making Behavior: A Four Dimensional Typology. Western Reserve University. USA

[12] Bazermann, Max. H.,Don A. Moore..1970. Judgment in Managerial Decision Making. 7-th ed. USA, p2-3

[13] Bazermann, Max. H.,Don A. Moore..1970. Judgment in Managerial Decision Making. 7-th ed. USA, p2-3

[14] Bazermann, Max. H.,Don A. Moore..1970. Judgment in Managerial Decision Making. 7-th ed. USA, p2-3

[15] Bazermann, Max. H.,Don A. Moore..1970. Judgment in Managerial Decision Making. 7-th ed. USA, p2-3

[16] Bazermann, Max. H.,Don A. Moore..1970. Judgment in Managerial Decision Making. 7-th ed. USA, p2-3

[17] Nicolas, Rolland. 2004. Knowledge management impacts decision making process. Journal of Knowledge Management; 2004; 8, 1; ProQuest pg. 20

[18] Perry, Patsy. 2013. The decision-making process of luxury fashion retail buyers in Greece. Journal of Fashion Marketing and Management Vol. 18 No. 1, 2014 pp. 85-106

[19] Margherita, Alessandro. 2014. Business process management system and activities: Two integrative definitions to build an operational body of knowledge. Business Process Management Journal Vol. 20 No. 5, 2014 pp. 642-662

[20] Balasubramanian, S;Gupta, Mayank. 2005. Structural metrics for goal based on business process design and evaluation. Business Process Management Journal; 2005; 11, 6; ABI/INFORM Complete pg. 680

[21] Michael Rohloff. 2010. Advances in business process management implementation based on a maturity assessment and best practice exchange. Inf Syst E-Bus Manage (2011) 9:383-403

[22] Santos Fabiana Jack Nogueira, Claudia Cappelli and Flávia Maria Santoro, Julio Cesar Sampaio do Prado Leite and Thar's Vasconcelos Batista 2012.Aspect-oriented business process modeling: analyzing open issues. Business Process Management Journal Vol. 18 No. 6, 2012 pp. 964-991

[23] Barros, Oscar. 2007. Business process patterns and frameworks: Reusing knowledge in process innovation. Business Process Management Journal Vol. 13 No. 1, 2007 pp. 47-69

[24] Inc.Com. Why the start Up Fail from http://www.inc.com/geoffreyjames/the-7-real-reasons-startups-fail-and- what-to-do-instead.html

[25] Schaffer/Willauer: strategic Planning as a Learning Process

[26] Article about The top 20 percent start ups fail from CBInsight: The top 20 percent start ups fail

[27] Saunders, Mark.Philip Lewis. Adrian Thornhill. 2009. Reserch methods for business student's 5th-ed. London 